\title{
2 Site-Specific Installation Art in Historical Perspective
}

Keywords: minimal art, avant-garde, public space, globalization, Miwon Kwon, Richard Serra

"Here, in fact, site-specificity arises precisely in uncertainties over the borders and limits of works and site."

Nick Kaye ${ }^{1}$

The argument in this chapter starts with a discussion of the art historical discourse on site-specific installation art. Artists as well as critics have explored various notions of site specificity, usually in concordance with successive art historical periods: the first "wave" of site-specific installations created during the late 1960 s and early 1970s, and a second period, from the 1980 s and early 1990 until today. The chapter elucidates several art historical perspectives on both periods and the shifts occurring in the relationship between artists and museum institutions, between the artwork and the site. Furthermore, it is important to realize that site-specific installation artworks are highly diverse in form, content, and meaning. For the current purpose of developing a model with an eye to the artworks' perpetuation, a chronological approach is only partly effective. A further abstraction in categorization is needed, focusing on the network of site-specific functions and their changes over time. To this end, a selection of relevant notions elucidate the extended lives of site-specific installations, which I derive from case studies and observations made by artists and art historians

1 Nick Kaye, Site Specific Art: Performance, Place, and Documentation (London: Routledge, 2000), 215 .

Scholte, T., The Perpetuation of Site-Specific Installation Artworks in Museums. Staging Contemporary Art. Amsterdam: Amsterdam University Press 2022 DOI: $10.5117 / 9789463723763 \_$CHO2 
in this respect. The discussion is a prelude to chapter 3 , in which I take the vocabulary for site-specific installation artworks one step further by employing a triadic set of spatial functions, which I derive from Henri Lefebvre's theory on space.

\subsection{The Rise of Site-Specific Installation Art: Criticism Towards the Established Art World}

There is no particular art movement or art form called "site-specific installation art." Nevertheless, site specificity has dominated the art discourse for decades. In particular, Miwon Kwon has built an extensive theoretical framework for site-specific installation art by analysing the development of site-specific installations from the 1960 s onwards in two seminal publications, both bearing the title One Place after Another. ${ }^{2}$ Historically, the interest in site specificity came to the fore in the 1960s, together with major art movements such as conceptual art, minimal art, Art in Public Space, Happenings, and performances. Kwon focuses on the influences of Minimalism for identifying the first category of her typology, indicated as "phenomenological" site specificity:

Emerging out of the lessons of minimalism, site-specific art was initially based in a phenomenological or experiential understanding of the site, defined primarily as an agglomeration of the actual "physical" attributes of a particular location (the size, scale, texture, and dimension of walls, ceilings, rooms; existing lighting conditions, topographical features, traffic patterns, seasonal characteristics of climate, etc.), with architecture serving as a foil for the art work in many instances. ${ }^{3}$

However, at the core of her critical theory is a second group of works, indicated as "social-institutional," in which artists worked with "the actuality of a location (as site) and the social conditions of the institutional frame (as site)." It was a vital element in the artistic practice of the 1960s and $1970 \mathrm{~s}$ to investigate institutional critique and reconfigure the site as

2 See footnote 32 in chapter 1.

3 Miwon Kwon, One Place After Another. Site-Specific Art and Locational identity (Cambridge, MA: The MIT Press, 2002), 3.

4 Kwon, One Place After Another, 44. 
[...] a relay or network of interrelated spaces and economies (studio, gallery, museum, art market, art criticism), which together frame and sustain art's ideological system. Works by artists such as Michael Asher, Daniel Buren, Hans Haacke, and Mierle Laderman Ukeles are seen as challenging the hermeticism of this system, complicating the site of art as not only a physical arena but one constituted through social, economic, and political processes. ${ }^{5}$

Kwon's incentive to develop a theoretical framework originated, largely, from institutional practices of a later date, the 1990s, when site-specific works from previous decades were collected and re-exhibited by commercial galleries and museums. Kwon points to the paradox that site-specific artworks resulting from critical strategies of the avant-garde were being incorporated into the very same system the artists once opposed. ${ }^{6}$ I will return to Kwon's viewpoint in this matter later on in this chapter.

In general, trends of the 1960s and 1970s gave primacy to notions of time and place, as well as to "process" and "presence." In The Fall of the Studio. Artists at Work, art historians Wouter Davidts and Kim Paice describe how artists abandoned the studio "as the unique and artisanal space of production." Space and place were among the most favoured means to reach beyond the established art system. Art in situ was created in all kinds of public spaces, including empty factories, office buildings, and alternative exhibition places, often run by the artists themselves.

A link with Art in Public Space and land art is frequently made when art historians explain the rise of site-specific installations during the late $1960 s$. Well-known examples of those art forms are, among others, Daniel Buren's painted stripes on buildings and street furniture, Christo and Jeanne-Claude's textile wrappings of buildings and bridges, and Earthworks created by Robert Smithson or Walter de Maria. Like Miwon Kwon, Davidts and Paice refer to artistic statements that establish a connection between the physical location and a critical take on the economic power of the art market. Because they were physically rooted in the site, these artworks were thought to resist commodification and distribution, an effective strategy to circumvent the market. ${ }^{8}$ Like no other artistic approach,

5 Kwon, One Place After Another, 3.

6 Kwon, One Place After Another, 2.

7 Wouter Davidts and Kim Paice, The Fall of the Studio. Artists at Work (Amsterdam: Valiz Publishers, 2009), 76 .

8 James Meyer, "The Functional Site or The Transformation of Site Specificity," in Space, Site, Intervention. Situating Installation Art, ed. Erika Suderburg (Minneapolis: University of 
works created on site provoked a critical stance towards the underlying mechanisms of the art system. Davidts and Paice illustrate this view in the following statement on Daniel Buren's coloured stripes on buildings in public space:

Through their specific application on a given site or support, the stripes aim to elucidate the material conditions of the work of art and its various modes of production, presentation, and reception. This undertaking, according to Buren, continues to oblige him to work "on site." ${ }^{\text {9 }}$

This thought is followed by one of Buren's own statements about the inseparability of his works and the sites for which they are produced:

"In situ" means, at least in my understanding of it, that there is a voluntary bond between the site of reception and the "work" that is produced, presented and exhibited there. ${ }^{10}$

By working directly with the conditions of the site, artists gave expression to their aversion to the ideology of the white cube, a term coined by artist and theorist Brian O'Doherty in $1976 .^{11}$ The white cube was the prevailing paradigm of modernist art - "a place deprived of location" - representing the claim of a universal form of art "with a direct line to the timeless, a set of conditions, an attitude. ${ }^{12}$ In contrast to the supposed neutrality of the exhibition space, artists employed the possibilities of the space itself as constituent for the artwork's meaning and emphasized their own presence and gestures in space. This view corresponds to the category of phenomenological site specificity identified by Kwon.

The interconnectivity with the actual location encouraged visitors of site-specific installations to explore the space of the installed artwork and its immediate surroundings; their own bodily movements were an

Minnesota Press, 2000), 25; Miwon Kwon, "One Place after Another: Notes on Site-Specificity," in Space, Site, Intervention. Situating Installation Art, ed. Erika Suderburg (Minneapolis: University of Minnesota Press, 2000), 40, 42-43; Mark Rosenthal, Understanding Installation Art. From Duchamp to Holzer (Munich: Prestel Verlag, 2003), 73; Claire Bishop, Installation Art. A Critical History (London: Tate Publishing, 2005), 17-20, 32.

9 Davidts and Paice, Fall of the Studio, 66.

10 Daniel Buren recited in Davidts and Paice, Fall of the Studio, 66.

11 Brian O'Doherty published a series of three articles in the journal Artforum in 1976. These articles have been republished in Brian O'Doherty, Inside the White Cube: The Ideology of the Gallery Space (Expanded Edition) (Berkeley: University of California Press, 1986).

12 O'Doherty, Inside the White Cube, 80. 
intrinsic part of the experience. Instead of looking at the art object, art critics observe, viewers of site-specific installations are surrounded by its composition in space, redirecting the focus from the creator and the autonomous art object to the position of the visitor. ${ }^{13}$ The visitor, in turn, undergoes a heightened perception of the here and now and of the "hidden" ideologies of the place in which the work is presented. As James Meyer states:

The body of site specificity was a physicalised body, aware of its surroundings, a body of heightened critical acuity. Thus, the premise of site specificity to locate the work in a single place, and only there, bespoke the 1960 s' $^{\prime}$ call for Presence, the demand for the experience of "being there."14

Site-specific installation artworks of the 1960 s and 1970s were imbued with a critical stance towards the institutions, which art historians explain in two different ways: the artworks represented a breach with the established art system of trade and modernist "neutrality" of the exhibition space; and secondly, they brought into focus the experience of art in "real life," represented by the inseparable bond between the artwork and the physical site. That said, the terms of phenomenological and institutional site specificity do not necessarily apply to all site-specific installation artworks created in the 196os and 1970s, and the terms may overlap when applied to practice. Moreover, Kwon acknowledges that, although her typology is presented in chronological order (as we shall also see below), these are "not stages in a linear trajectory of historical development." ${ }^{\prime 5}$ In fact, in today's cultural practices, similar approaches of phenomenological site specificity and institutional criticism still exist.

\section{Institutional Perspective}

Despite the critical attitude, it was common practice for vanguard artists to collaborate with progressive curators and sometimes they created site-specific installations in commercial galleries and museum spaces. Land art projects, in addition, could find their ways into the distribution system of museums and commercial galleries in the form of documentary

13 See Bishop, Installation Art, 11; Kwon, "Notes on Site-Specificity," 38; Nicolas De Oliveira, Michael Petry, and Nicola Oxley, Installation Art (London: Thames and Hudson, 1994), 13-14.

14 Meyer, "Functional site," 26.

15 Kwon, "Notes on site-specificity," 46. 
material relating to the project, such as sketches, photographs, and films. These derivatives were, in the words of Lucy Lippard, "consumed" by gallery visitors, who were unable to experience the art itself at the location. ${ }^{16}$ An overtly more critical stance was taken by Brian O'Doherty in his comment that the avant-garde of the 1960 os and 1970s "never attacked the idea of a gallery, except briefly to promote the move to the land which was then photographed and brought back to the gallery to be sold." ${ }^{17}$

That said, the site of the gallery had indisputably turned into a place of questioning the art system, as curator Christian Rattemeyer highlights in his reflection on site-specific art of the avant-garde. He observes that artists working in situ

[...] transformed the nature of art and its materials, questioning how and by whom art can be made, where a work of art can exist and even whether it needs to exist as a physical object at all. ${ }^{18}$

One of the most famous, progressive gallerists at the time was Leo Castelli (1907-1999), who invited young artists to respond in their own ways to the conceptual and literal space of art. In 1968, Castelli asked Robert Morris to curate an exhibition of conceptual and processual art for the Castelli Warehouse. Nine artists participated in the exhibition - called 9 at Castelli most of whom became famous artists later on. Quite a number of site-specific artworks were presented at this show, but most of them did not survive, because they were destroyed immediately afterwards. ${ }^{19}$

Other curators followed soon after, and within one year - 1969-several major exhibitions featured site-specific installations in prominent museums worldwide: Op losse schroeven in Stedelijk Museum Amsterdam, When Attitudes Become Form in Kunsthalle Bern, and Spaces in MoMA New York. ${ }^{20}$

16 Lucy Lippard, "Land Art in the Rearview Window," in Surface Tension: Problematics of Site, ed. Ken Ehrlich and Brandon Labelle (Downey: Errant Bodies Press, 2003), 59.

17 O'Doherty, Inside the White Cube, 93.

18 Christian Rattemeyer, Teresa Gleadowe, Charles Harrison, Harald Szeemann, and Wim Beeren eds., Exhibiting the New Art. "Op Losse Schroeven" and "When Attitudes Become Form" 1969 (New York: Distributed Art Publishers, 2011), 14.

19 In the exhibition 9 at Castelli (1968) the following artists participated: Giovannni Anselmo, Joseph Beuys, William Bollinger, Rafael Ferrer, Eva Hesse, Stephen Kaltenbach, Bruce Nauman, Alan Saret, Richard Serra, Keith Sonnier, Gilberto Zorio.

20 Op Losse Schroeven. Situaties en Cryptostructuren, Stedelijk Museum Amsterdam, took place from 15 March to 27 April 27, 1969 and was curated by Wim Beeren. Live in Your Head. When Attitudes Become Form, Kunsthalle Bern, took place from 22 March to 27 April 1969 and was 
Most site-specific installations were made with ephemeral and temporary materials, signalling the influences of conceptual art and process art. Their site specificity and ephemerality challenged common curatorial practices, as the art historian Julie Reiss notes in From Margin to Center: The Spaces of Installation Art:

Conceptual, Process, and installation works usually could not be seen by curators before they were installed, but were created by the artist, in situ, shortly before the exhibitions opened to the public. ${ }^{21}$

The exhibition Spaces was a typical example of this changed practice. Reiss explains that the usual processes of selection and valuation did not take place beforehand, meaning the curator could not be ensured of the quality of the works. Besides, immense pressure was put on the technical staff and the conservators, who had to accommodate gallery spaces to the requirements of spacious works of art, while the artists brought materials into the building that might pose a risk to the collection - such as mist or live spruce trees. ${ }^{22}$ These are usually severe enemies of the museum environment, and staff members had to take the necessary measures to protect the collection, the building, and the public. ${ }^{23}$

Site-specific installation artworks dating from the 1960 s and $1970 \mathrm{~s}$ intentionally challenged institutional policies and practices. Gallery spaces could be transformed into laboratories for artistic experiment or

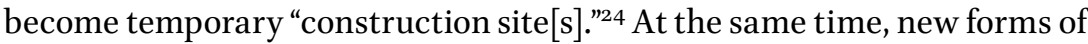
co-operation and negotiation between artists and curators arose, establishing networks of collaboration that could last a lifetime. ${ }^{25}$ In that respect, Brandon

curated by Harald Szeeman. Spaces, MoMA, took place from 30 December 1969 to 1 March 1970 and was curated by Jennifer Licht. For a detailed description of the first two exhibitions, see: Rattemeyer et al., Exhibiting the New Art. For an elaborate discussion of Spaces, see: Julie H. Reiss, From Margin to Center: The Spaces of Installation Art (Cambridge, MA: The MIT Press, 1999), 87-106.

21 Reiss, The Spaces of Installation Art, 81.

22 Reiss, The Spaces of Installation Art, 87, 88, 93.

23 For example, a room created by Larry Bell was completely darkened. Reiss, The Spaces of Installation Art, 93 .

24 Kim Paice uses the term "construction site" in relation to Robert Morris's Continuous Project at the warehouse of Leo Castelli's gallery in New York, to which the artist transported huge amounts of raw materials and reworked them during live performances. The project lasted from 28 February to 22 March 1969.

25 An example of a long-lasting relationship between artists and curators is Harald Szeemann's directorship of Kunsthalle Bern. In 1969, Szeeman curated When Attitudes Become Form and in successive years, opened numerous exhibitions with artist friends whose studios he frequently 
Labelle and Ken Ehrlich made a relevant comment in Surface Tension: Problematics of Site. The authors state that, alongside the production of site-specific art, the institutional context and artistic practices became increasingly intertwined:

In this sense, "site" might function as an operational term through which to gauge practice - it is both the physical location of presentation and the intrinsic negotiations site specificity entails. ${ }^{26}$

Hereafter and in continuation of the discussion of the notions of socialinstitutional and phenomenological site specificity, different perspectives on the extended lives of site-specific installation artworks will be elaborated. Two examples created by Richard Serra will illustrate the artist's view regarding the spatial design and sociocultural context of his site-specific art. The first is Serra's seminal installation in public space Tilted Arc (1981); the other is Serra's performance-based installation Splashing (1968).

\subsection{Unmoveable or Moveable? The Case of Richard Serra's Tilted Arc}

One of the most controversial examples of site-specific art is Richard Serra's Tilted Arc (1981), commissioned by the U.S. federal government for the Federal Plaza in New York. ${ }^{27}$ [Figure 5]

The work consists of a large wall made of Corten steel, measuring no less than $37 \times 3.70 \mathrm{~m}^{2}$. Therewith, Tilted Arc divides a large section of the square into two parts. A few years after the work was completed, neighbours and

visited. Due to this personal network and the archive he created, a remake of the original exhibition was possible with the co-operation of many participating artists: When Attitudes Become Form: Bern 1969/Venice 2013, curated by Germano Celant, Fondazione Prada, Ca' Corner della Regina, 1 June-3 November 2013. See, e.g., Marina Biryukova, "Reconsidering the exhibition When Attitudes Become Form curated by Harald Szeemann: form versus 'anti-form' in contemporary art," Journal of Aesthetics \& Culture 9, no. 1 (2017), https://www.tandfonline.com/doi/full/10.10 8o/20004214.2017.1362309.

26 Ehrlich and Labelle, Surface Tension, 10-11.

27 For a thorough analysis of the work by Richard Serra and its intellectual and perceptual basis, I refer to Rosalind E. Krauss, Richard Serra: Sculpture, ed. Rosalind Kraus, exhibition catalogue (New York: Museum of Modern Art, 1986). Tilted Arc is discussed by Douglas Crimp in “Serra's Public Sculpture: Redefining Site Specificity," in Richard Serra: Sculpture, ed. Rosalind Krauss, exhibition catalogue (New York: Museum of Modern Art, 1986), 41-56. 
Figure 5 Tilted Arc (1981, removed in 1989) by Richard Serra, Federal Plaza, New York City. Photo: Anne Chauvet. @ c/o Pictoright Amsterdam.

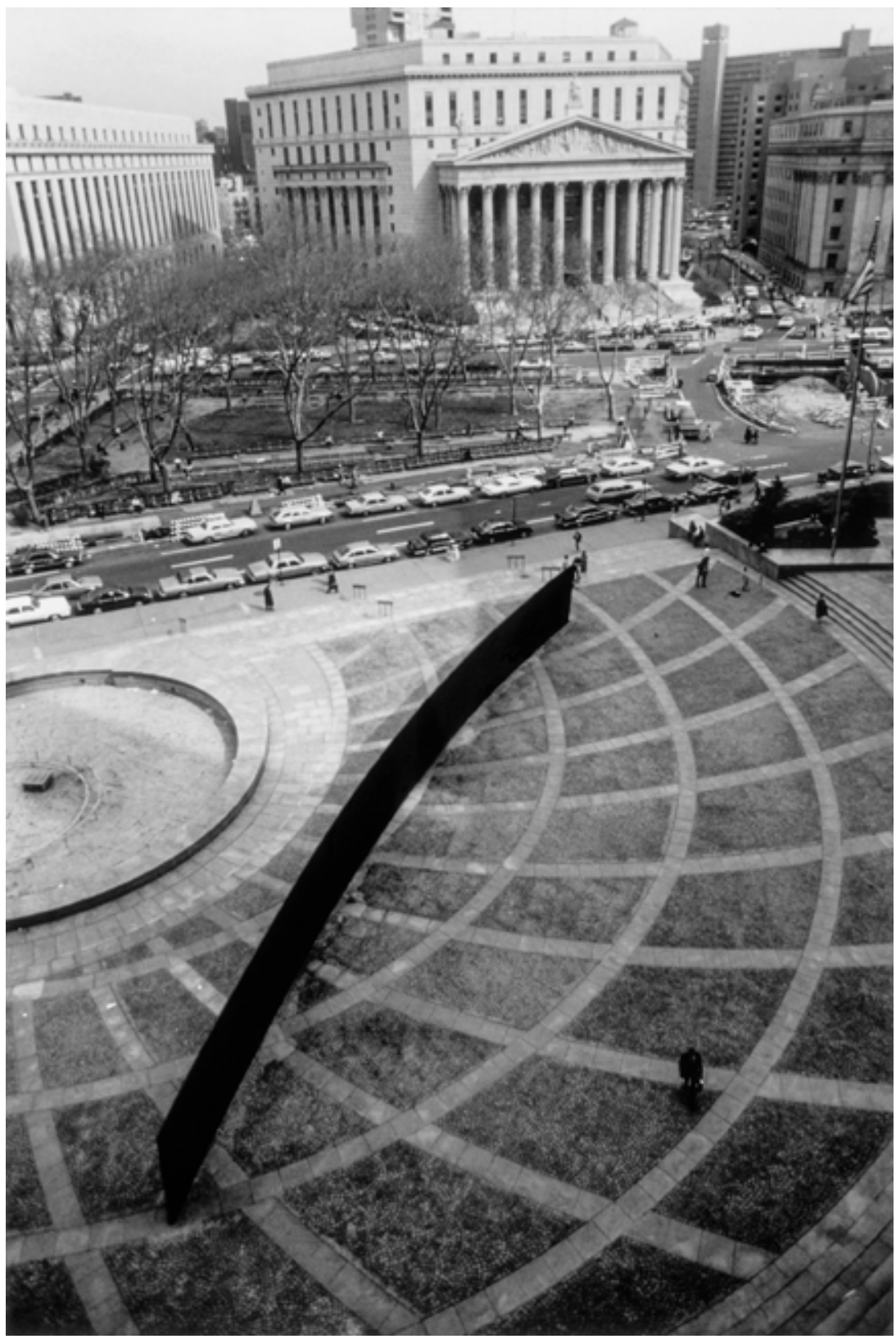


people working in the surrounding offices complained that, because the "wall" was placed in the centre of the square, the former social function of the plaza had been lost. ${ }^{28}$ The General Services Administration proposed to relocate Tilted Arc from the plaza to a scenic environment in the countryside where it would be "appropriately sited" and better appreciated by the public. ${ }^{29}$ Together with fellow artists, curators, and friends, Richard Serra started a lawsuit resulting in a famous public hearing in 1985. At this occasion, Serra declared:

Tilted Arc was conceived from the start as a site-specific sculpture and was not meant to be "site-adjusted" or "relocated." Site-specific works deal with the environmental components of given places. The scale, size, and location of site-specific works are determined by the topography of the site, whether it be urban or landscape or architectural enclosure. The works become part of the site and restructure both conceptually and perceptually the organization of the site. ${ }^{30}$

In the public hearing on March 1985, the issues of site specificity were addressed in an unprecedented way. On the one hand, Serra pointed out to his opponents the inseparability between the artwork and the site, in terms of their physical and optical dimensions. On the other hand, he objected to the fact that the government did not "respect the implications of the concept of site specificity," as it had been implied in the spatial design of the artwork that local pedestrians would need to adjust their routes when traversing the square. Hence, it could have been foreseen that the work would somehow interfere with the former social function of the square and the natural flow of the people. ${ }^{31}$

After a fierce debate between supporters and opponents, in 1989 it was decided that Tilted Arc would be removed and destroyed, in accordance with Serra's refusal to relocate the work. His statement that site-specific

28 For example, Joseph Liebman states: "I remember walking freely in the plaza, contemplating the examination of a witness, undisturbed by the presence of other people engaged in conversation or young lovers holding hands. I also remember my dreams of additional seating areas, more cultural events, temporary outdoor exhibits of painting and sculpture, and ethnic dance festivals." Clara Weyergraf-Serra and Martha Buskirk, The Destruction of Tilted Arc: Documents (Cambridge, MA: The MITT Press, 1991), 113 .

29 Memo from the Public Buildings Service to the responsible administrator of the General Services Administration William J. Diamond. See Weyergraf-Serra and Buskirk, Destruction of Tilted Arc, 31.

30 Richard Serra in Weyergraf-Serra and Buskirk, Destruction of Tilted Arc, 11-12.

$3^{1}$ Serra, Destruction of Tilted Arc, 13. 
art "cannot be moved without being destroyed" was effectuated by the Corten steel plates being carted off to a scrap metal yard, which the artist regarded an "accomplishment" of the process. ${ }^{32}$ Because of its destruction on 15 March 1989, Tilted Arc no longer exists as a physical work of art, but its life has been prolonged through many debates in art historical writings ever since, on site-specific art and the problem of relocation.

Art historian Douglas Crimp, who argued in support of Titled Arc at the lawsuit, notes that the case of Tilted Arc reveals "the radical aesthetics of site-specific sculpture," which is always politically charged. ${ }^{33}$ In his opinion, the crisis shows that neither the general public nor the government comprehended the implications of this radical and historical moment in artistic practice:

The work was conceived for the site, built on the site, had become an integral part of the site, altered the very nature of the site. Remove it and the work would simply cease to exist. ${ }^{34}$

Kwon takes a similar stance in One Place After Another - reminding us of an earlier statement, made by the installation artist Robert Barry, that site-specific art cannot be moved without being destroyed. ${ }^{35}$ (Barry made this statement in 1969, referring to his fragile room-filling installations made of nylon and iron wire.) Kwon points to the critical function of site-specific art

[...] of working against the physical and socio-political conditions of the site [and] simultaneously address the site as another medium, or another "language". Put a little differently, working against the site coincides with working against the modernist illusion of artistic autonomy. ${ }^{36}$

Relying on Barry's dictum and the controversy over Serra's Tilted Arc, Kwon develops a key for the discourse on site-specific installation art - namely, that this critical function is lost when the artwork is relocated. She extrapolates this view to an entire group of site-specific installations dating from the 
1960 s and 1970s, which had the function to "undercut the fallacy of the 'autonomy' of art and its institutions." ${ }^{37}$ Site specificity of this period is indeed seen as a new language or medium to question the conditions and hidden structures of the site.

Kwon's argument is also important for the topic of the perpetuation of site-specific installation artworks. The author takes her stance in reaction to an emerging trend of the late 1980s, when museums in Paris, New York, Los Angeles, and elsewhere started to re-exhibit, collect, and refabricate site-specific installations from previous decades. ${ }^{38}$ It is not by coincidence that fertile soil was found for opposing this practice, because, as Kwon indicates, it is precisely the mobilization of site-specific works that deprives them of their critical potential and sets a new norm in which the connection between artwork and site is rendered irrelevant. On the one hand, Kwon agrees that the re-execution of "unrepeatable" works offers an opportunity to reconsider their historical significance. On the other hand, she points to what is lost:

But the very process of institutionalization and the attendant commercialization of site-specific art also overturn the principle of placeboundedness through which such works developed their critique of the ahistorical autonomy of the art object. ${ }^{39}$

Seen from this perspective, there might be a problem with the continued existence of site-specific installation artworks in a museum context, because of the disruption of the historical ties to the location. Accountability for the afterlife of site-specific installations is attributed by Kwon (and others) to the art market and art institutions who have a commercial interest, and to the artists who, most of the times, co-operated with museums and galleries for a remake and/or acquisition..$^{40}$ According to Kwon,

37 Kwon, One Place After Another, 40.

38 Exhibitions featuring site-specific art from the 1960 s and 1970 in this period include L'art conceptuel, une perspective (1989) in Musée d'art moderne Paris; New Sculpture, 1965-75: Between Geometry and Gesture (1990) and Immaterial Objects (1991), both in the Whitney Museum, New York; and Out of Actions: Between Performance and the Object (1998) in Museum of Contemporary Art, Los Angeles.

39 Kwon, One Place After Another, 38.

40 An exception to this "rule" is a collection of artworks created during the 1960 os and 70 s (including site-specific installations) that was acquired by the Italian collector Giuseppe Panza di Biumo. The artists did not always authorize reinstallation and sometimes no longer acknowledged the reinstalled piece as their art. To ensure research, preservation and presentation of the Panza Collection, which is now with the Guggenheim Museum, New York, a grand-scale project was 
the heyday of this practice was in the 1990s, but it also continued in later years, up to today. Does this imply that all recreations and relocations of site-specific installations should be considered historical falsifications? Looking at site specificity as a dynamic network, I see a counterargument in the fact that collaboration between artists and visionary curators, which started in the 196os and 1970s, often continued during later years. Besides, the recreation of site-specific installations can also be envisioned as a process of transformation, in which the performative qualities of site specificity come to the fore. To illustrate this point, I will briefly discuss Richard Serra's Splashing, which was literally the outcome of a performance and in which Serra took the conditions of the site as a leading principle.

\subsection{The Extended Life of Richard Serra's Splashing}

Richard Serra created his first performance, Splashing (1968), by throwing molten lead in one of the corners of the Castelli Warehouse in New York. ${ }^{41}$ The lead hardened at the juncture between the wall and the floor, demarcating the dimensions of the gallery space. Douglas Crimp describes the initial iteration of Splashing as follows:

There it was, attached to the structure of that old warehouse on the Upper West Side, condemned to be abandoned there or scraped off and be destroyed. ${ }^{42}$

The result of Serra's performance was an installation that was defined by the specifics of the site and lasted no longer than the exhibition 9 at Castelli, which was curated for the gallery's warehouse by the artist Robert Morris. ${ }^{43}$ Most of the artworks on show were process-related and site-specific, and most of them have never been recreated. Splashing, however, was reperformed by Richard Serra many times, resulting in his Splash pieces that were

carried out by the Guggenheim Museum between 2010 and 2019: The Panza Collection Initiative. https://www.guggenheim.org/conservation/the-panza-collection-initiative (last accessed 22 April 2021).

41 Rosalind Krauss places Richard Serra's Splash pieces extensively in an art historical perspective in her essay "Portrait of the Artist. Throwing Lead," in Richard Serra: Sculpture, 15-39.

42 Crimp, Museum's Ruins, 151.

439 at Castelli, organized by Robert Morris for the Castelli Warehouse, was open from 4 to 28 December 1968, between 1 and 5 PM. 
defined by the conditions of the new location. [Figure 6] Serra repeated the performance of throwing lead in later years, even with the help of assistants. In hindsight, he emphasizes the repeatability of the Splash pieces, making no distinction between temporary or permanent iterations:

I did one at the Castelli Warehouse, just a very straight line. And then subsequently, I think about four months later, I did one in the Whitney Museum. And over the last twenty or twenty-five years I have been doing them every three or four years as the occasion allows, or as a museum calls for one or as an exhibition comes up. The museum in Tilburg [De Pont, 1992] asked me to build a permanent one. The one in SFMOMA [1995] is the second permanent one, and I think probably within this next six months I am going to build one in Hamburg [Kunsthalle Hamburg, 1996].44

Serra's statements can be read as a notion that site specificity is a means to define the artwork for a specific occasion, just like the lead is a medium to shape its form through the artist's own bodily movements. Serra's Splash pieces crystallize into (semipermanent) installations that last as long as they are not removed and therewith still follow the dictum that to remove the work is to destroy it. But different from his stance concerning the relocation of Tilted Arc (being a site-specific work in public space), it is part of the concept of the Splash pieces that the performance can be situated in different locations, making the installation site-specific time and again. From his own statement, the artist regards the gallery primarily as a formal space of which the dimensions determine the shape of the artwork, and not so much as a place to express a critical socioinstitutional stance. In this respect, it is worth looking at the following statement by Serra during an interview with Craig Owens in 2016:

I think I am a transitional figure. If anything, I would call myself a poststructuralist, not a postmodernist. I'm involved with the evolution of form, the connection where space and matter meet. One of the things that form constantly has to do is reach a point where it pushes back against content. [...] Form is something that metamorphoses into other forms. It has its own internal logic that can be dispelled and migrate into other forms. ${ }^{45}$

44 The interview with Richard Serra was recorded and published by the San Francisco Museum of Modern Art in 1995, https://www.youtube.com/watch?v=LjvVEN2v8rY.

45 Interview with Richard Serra by Craig Owens in The Guardian, 1 October 2016. 
Figure 6 Gutter Splash Two Corner Cast (1992/1998) by Richard Serra. Collection Museum De Pont, Tilburg. Photo: courtesy De Pont. $\odot$ c/o Pictoright Amsterdam.

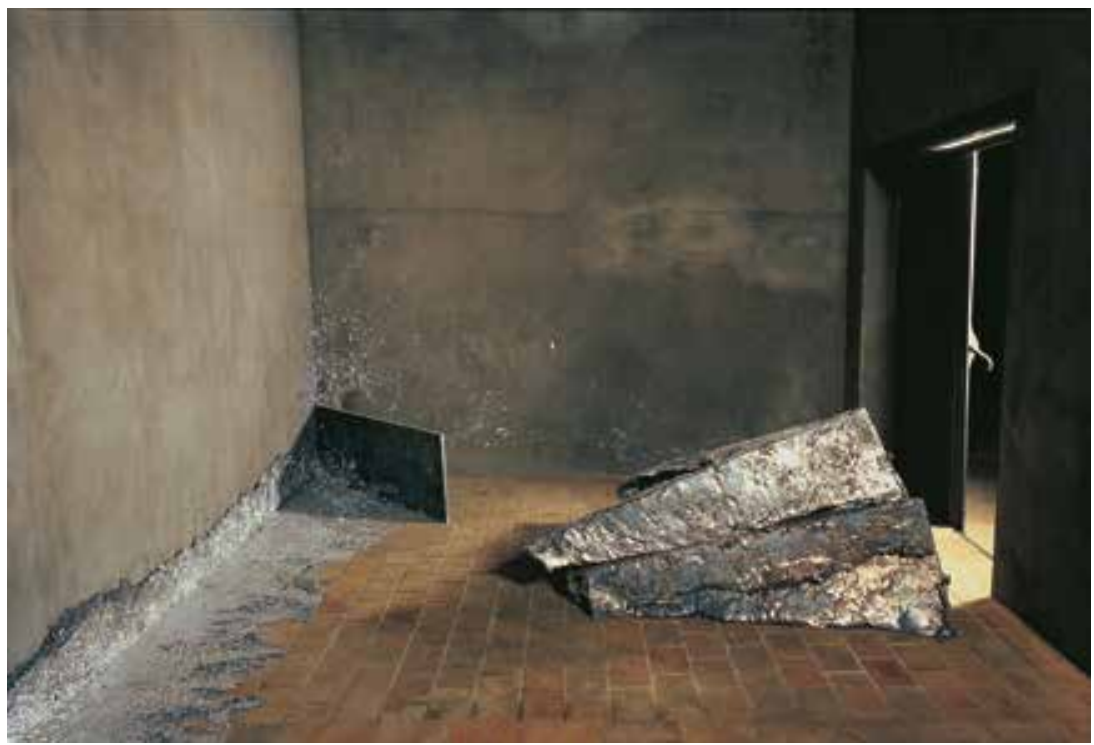

Serra's account might be a reason to place the Splash pieces in Kwon's category of phenomenological site specificity, the kind of work that is rooted in the physical conditions of the site. In her chapter "Unhinging of site specificity," Kwon criticizes the recreation of "unrepeatable" artworks, for which she takes Serra's Splashing as an example. ${ }^{46}$ She stresses the mechanisms of commodification when site-specific works are repeated, hence losing their historical and critical potential:

With the co-operation of the artists in many cases, art audiences are now offered the "real" aesthetic experiences of site-specific copies [...] As Susan Hapgood has observed, the once-popular term 'site-specific,' has come to mean "movable under the right circumstances, shattering the dictum that "to remove the work is to destroy the work."

It can be argued that the memory of the historical piece should have prevailed by not repeating the performance. However, taking the perpetuation 
of site-specific installations as a starting point and with an eye to Serra's own statements, I would argue that, even though each performance was adjusted to the respective context, the concept of the work remained the same, offering museum audiences a materialized site-specific installation. Indeed, a prerequisite for this view is that the artist executed the performances himself by throwing the lead into the corners of the space and by authorizing the installation resulting from it. Things might become more complex when others take over the role of the performer, therewith diminishing or replacing the artist's physical, bodily involvement. ${ }^{48}$ This happened in later years of Serra's career, for example with the execution of a Splash piece for SFMOMA in 1995, Gutter Corner Splash: Night Shift (1969/1995). In this case, the artist was supported by his assistants, but he was still present as a coworker and supervisor, and authorized the installation. ${ }^{49}$ That said, I still agree with Kwon that there are limits to the historical integrity of recreating site-specific installations, for example, when performance elements are part and parcel of the production process. In chapter 3 and the case study chapters, the question returns to what extent change and continuity can be paired with one another, or when the borders of integrity are crossed.

\section{Historical Evidence of Site Specificity}

Memories of site-specific installations are usually based on photographic documentation, and sometimes on narratives and discourses, as in the case of Tilted Arc. This point leads back to the role of photographs in the extended lives of site-specific installation artworks, which Martha Buskirk observed in the case of Allan Kaprow's Yard (see chapter 1). Buskirk indicates the importance of photography for reiterations of ephemeral works of art as follows:

Thus the photograph is part of a process that is both fixed and fluid, allowing comparison of the far-flung examples of a work that cannot be understood as singular, even as the work has, after each disturbance, largely settled back into its identity with photographs [from the past]. $5^{\circ}$

48 It goes beyond the scope of this discussion, but performance artworks are often re-executed by others, with the seminal example of reperformances of works by Marina Abramović.

49 Richard Serra's Gutter Corner Splash: Night Shift (1969/1995) has been created for SFMOMA with the help of his assistants, who splashed the lead in the corner under his supervision. For the creation process, see: https://www.sfmoma.org/watch/richard-serra-throws-molten-leadinside-sfmoma/ (last accessed 22 April 2021).

50 Buskirk, Creative Enterprise, 137. 
The role of photography and moving image cannot be underestimated in the daily practice of contemporary art museums that aim to keep spatiotemporally defined artworks alive and, in one way or another, develop "control mechanisms" for managing these complex works of art. Martha Buskirk points to the role of the artists in this process, who foresee a trajectory of relocation from the start. Recontextualization, she states, is often a "technique that artists [...] choose to employ as a key element of the artistic process" - they often collaborate with the institutions "in the process of organizing, staging, and documenting their site-dependent or event-based projects. ${ }^{11}$ She concludes that, during musealization, conservation, and presentation, an ongoing dialogue takes place between the artist and art institutions, which has the ability "to absorb, even foster, what once appeared to be critical discourse. ${ }^{52}$ Apart from this active engagement with preserving the past, in recent times, museums actively help to produce the art of the present. ${ }^{53}$ Hence, in view of the past, present, and future of site-specific installation artworks, it is vital to look into the entire network of actors involved, sharing the responsibility of their perpetuation, and to examine to what extent artworks are conceived as strictly spatiotemporal defined or as an artistic strategy that incorporates repeatability.

\section{Site Specificity as Artistic Strategy}

Various strategies may come into play during the processes of musealization, conservation, and reinstallation of site-specific installation artworks. The artist's intention is without doubt of primary importance, but personal networks, collaboration with museums, the know-how of assistants and professional staff, theoretical discourses, and technical means, such as photographs and other documentation can all play a part in their perpetuation.

The conservation scholar Tina Fiske offers an insightful example with her analysis of Andy Goldsworthy's site-specific installation White Walls (2007), in which she takes a processual point of view. ${ }^{54}$ The installation consists of slabs of wet porcelain clay, which were applied to the four walls of the Lelong gallery space in New York. The idea was that, when the clay dried, it would harden and crack, and eventually fall to the floor, as had happened with Goldsworthy's other clay installations. However, with the

Buskirk, Creative Enterprise, 10, 17.

Buskirk, Creative Enterprise, 7.

Buskirk, Creative Enterprise, 3.

Andy Goldsworthy created White Walls for Galerie Lelong, New York. 
2007 iteration, it appeared that the process was unpredictable and could be highly intrusive. Fiske explains that, because there is a bonding of the clay and the substrate, layers of wall paint were also taken off when the slabs fell to the floor, "revealing the physical substance of the walls and the traces of previous interventions by other artists." In the end, the artwork turned out to be a "material embodiment" of a "destructive" process that involved many participants, including the work of artists previously on show in the gallery. 55

Fiske takes the example as her starting point for a reflection on the "iterability" of site-specific installation artworks that have the potential of being repeated. Following Derrida's notion of différance, she holds the view that this kind of works resemble both identity and difference. ${ }^{6}$ Most of the time, she argues, a site-specific installation loses the "physical bond to its originating event or context of inscription" after the exhibition period. ${ }^{57}$ A period of "absence" starts when the artwork is disassembled; some parts may be put in storage, and materials that were intentionally temporary will be thrown away. Key to Fiske's argument is that, after such intermission and dormant state of the artwork, a radical understanding is required to reinstall the work (the author compares this process to a strategy of "translation"). ${ }^{8}$ Professionals need to understand the artwork's identity and genesis, and should have the know-how to reactivate the work's site specificity in terms of différance. Site specificity is thus seen as a process of reinterpretation (which, in the case of White Walls, took an unintentional and dramatic turn, because it revealed other site-specific works as well). Fiske concludes that the "iterability" of a site-specific work in a new context considers "a particular mode of repetition that mobilizes notions of breach, absence and difference. 59

Fiske's notion of iterability is also at the heart of the current investigation. From her discussion of White Walls, the insight can be drawn that site specificity is often a strategy to set a process in motion that can be

55 Tina Fiske, "White Walls: installations, iteration and difference," in Conservation: Principles, Dilemmas and Uncomfortable Truths, ed. Alison Richmond and Alison Bracker (Amsterdam: Elsevier, 2009), 229.

56 Tina Fiske offers an in-depth reflection on the conservation and presentation of site-specific installations in a museum context, which she understands as an exemplification of Derrida's notion of "iterability": a particular mode of repetition that "rather than 'aspiring to the fulfilment of the original,' searches or reaches beyond the original itself." Fiske, “White Walls," 234-235.

57 Fiske, "White Walls," 233.

$5^{8}$ Fiske, "White Walls," 236.

59 Fiske, "White Walls," 232. 
repeated with respect to the identity of the work, accepting the differences that may occur - sometimes even unintended. Another alluring argument is that sometimes radical solutions are taken by the artist and/or custodians in order to "translate" the artwork from one context to another.

An explicit call to conceive site specificity as a process or modus operandi has also been made by artist and philosopher Kevin Melchionne. Rejecting Crimp's belief in "the singularity of place" in site-specific art (as demonstrated with the case of Tilted Arc), Melchionne states that site specificity "denotes an increasingly complex set of practices." ${ }^{60}$ The relocation and/ or reiteration of a site-specific installation does not necessarily mean the work has lost its intended meaning:

the possibility of relocating site-specific works depends on an alternative conception of the relation between the ontology of space and the meaning of the work. Typically, in discussions of site-specificity, it is assumed that the meaning of the work relies on qualities that define a particular place as unique. [But] singularity is not their only quality. Those aspects of the place which constitute its singularity may not be the most relevant for a work of art made for the place. ${ }^{61}$

Instead of adhering too much to the artwork's physical rootedness, Melchionne suggests an approach of differentiating between different modes of site specificity. Scholars and curators, he states, should determine what the artist aims to achieve with a strategy of working in a site-specific way. To this end, he offers a list of possibilities: engagement with the formal structures of the site, interaction with the art system (institutional criticism) and/or with the viewer (in experiencing the installed work), incentives provided by a contest or a commission for a site-specific work (in galleries or public space), engagement with the historical and/or sociopolitical meaning of a place, and so forth. ${ }^{62}$ Following Melchionne's multilayered perspective on site specificity, I believe that the research into the perpetuation of sitespecific installations can be guided by the analysis of a set of site-specific strategies, applied by the artists, and the ways in which these are reactivated or disregarded in future iterations.

6o Kevin Melchionne, "Rethinking Site-Specificity: Some Critical and Philosophical Problems," Art Criticism 12, no. 2 (1998), 47.

61 Melchionne, "Rethinking Site-Specificity," 45, 47.

62 Melchionne, "Rethinking Site-Specificity," 38-39. 
Firstly, however, I will continue my search for notions that can help identify the strategies and site-specific functions applied by the artist. Whereas, in the discussion so far the primary focus has been on the relationship between the artist and the museum institution, it is time to include the visitor, in a triangular relationship between the work, the surrounding space, and the spectator. As previously stated, various art historical movements have influenced the rise of site-specific installation art and references are frequenty made to minimal art - in particular when addressing the perception of the work and the position of the visitor in the exhibition space. ${ }^{63}$ This, in fact, is a further elaboration on the type Kwon identified as phenomenological site specificity.

\subsection{Site Specificity and the Viewer's Position in the Gallery Space}

During the 196os, minimal art dominated the art world with abstract images that are defined by their spatial dimensions, colour, surface, and the surrounding space. The visitor's own position in the exhibition space contributes to the perception of the work - accentuating the awareness of the visitor's presence in the here and now. With Minimalism, the spatial arrangement became part of the meaning of the artwork, redirecting the attention from the artwork (and its creator) to the visitor, as Douglas Crimp observes:

During the 196os, minimal sculpture launched an attack on the prestige of both artist and artwork, granting that prestige instead to the situated spectator, whose self-conscious perception of the minimal object in relation to the site of its installation produced the work's meaning. ${ }^{64}$

Crimp continues by stating that the viewer becomes "the subject of the work" in minimal paintings and sculptures. These artworks are only completed when the viewer is present. Moreover, these artworks incite a sense of introspection and self-awareness through the reciprocal relationship between the artwork, the viewer, and "the place inhabited by both. ${ }^{\prime 6}$ There

63 For the influence of minimal art on site-specific installations, see: Crimp, Museum's Ruins, 16-17; De Oliveira et al., Installation Art, 23; Kaye, Site-Specific Art, 25; Kwon, One Place After Another, 12-13; Meyer, "Functional Site," 25-26; Rosenthal, Installation Art, 64; Bishop, Installation Art, 77.

64 Crimp, Museum's Ruins, 16-17.

65 Crimp, Museum's Ruins, 154. 
are differences in opinion apropos of the comparison between minimal art and site-specific installations. Art historian Mark Rosenthal observes that minimal art is indeed influenced by the spatial co-ordinates, light conditions, and the visitors' trajectories through space. Installations of minimal art are "in tandem with and even embrace literal space, if only in a generic sense - wall, floor, ceiling, corner." The author continues by stating that the artworks on display are seldom site-specific in a strict sense because they are, in fact, quite moveable. ${ }^{66} \mathrm{On}$ the other hand, in reaction to the "regularity and [the] structures and grids" of Minimalism, site-specific working artists such as Richard Serra went a step further, because they truly intervened with the physical conditions of the space, engaging visitors in such a way that it might feel "uncomfortable." ${ }^{67}$

Site-specific interventions have their "own internal logic and formal integrity," which, as Rosenthal states, could be reinvigorated when the artwork is relocated to a different location provided that a new connection with the site is established: "Again, the viewer has a real time and space experience of that location in particular." ${ }^{68}$ Rosenthal shows that, with such radical gestures and interventions - worded by Serra as "attacking and restructuring" a given space - the integrity of the artwork would not necessarily be lost when the work is relocated and distributed to different places. ${ }^{69}$ These observations bring into focus the conception of the spatial design of the artwork as a site-specific function that can be repeated or reperformed at different locations. In that sense, the perpetuation of Serra's Splashing could be explained as a succession of reiterations and reactivations of the function of the spatial design, characterizing Serra's approach for this particular work of art.

\section{The Performativity of Site Specificity}

Like the authors mentioned above, performance scholar Nick Kaye draws a comparison with minimal art in his book Site Specific Art: Performance, Place, and Documentation. Looking at site-specific installations as radical interventions "into the gallery, the city, and other 'found' sites," he suggests to focus on what those artworks $d o$ :

66 Rosenthal, Installation Art, 64.

67 Rosenthal, Installation Art, 64.

68 Rosenthal, Installation Art, 66-67.

69 Richard Serra's citation comes from Rosenthal, Installation Art, 64. 
Although operating through a variety of disciplines and means, each [of these works] take their effect in performance..$^{70}$

Site specificity is brought to life in interaction with the surrounding context and, as Kaye states, provokes uncertainties about the distinctions "under which a work's integrity and place are fixed." ${ }^{11}$

What makes Kaye's argument relevant to the current research? First of all, he points us to the performativity of site-specific installations in the sense that these artworks activate the connection between the work and conditions of the (museum) site. Secondly, his view that site-specific works "trouble the oppositions between the site and the work," can be interpreted as a deliberate effect of site-specific installations: to address the gallery space as an "activated site" where the usual procedures and practices of the museum regime are challenged..$^{2}$ In a sense, his argument does not seem to diverge from the notion of institutional criticism made by Kwon and others, but Kaye underscores the iterability of this function, as a continuous potential for questioning the gallery space and the museum's organizational structure. By "conceiving the museum as a conceptual framework rather than a built form," the work is not only defined by the site, but, conversely, site-specific installations define the site just as well. ${ }^{73}$

The above paragraphs discussed two main concepts regarding artistic strategies towards creating site-specific installations: minimal art of the 1960 and 1970s offered the notion that site specificity heightens the visitor's perception in the here and now. Secondly, Nick Kaye called attention to the "performativity" of site-specific installations, because they establish a reciprocal relationship between the artwork and the site. In respect of the latter, I would also call to mind Domínguez Rubio's statement that installation artworks behave as "unruly objects" through their capacity to shift the boundaries and traditional control mechanisms of the institution. Later on, in chapter 3 , I will return to this notion as well as to the idea that site-specific installations have agency to "perform" when discussing current theories and practices in the conservation of contemporary art. First, however, I will briefly introduce one particular site-specific installation that interfered with the usual practices of museum

70 Kaye, Site-Specific Art, 25.

71 Kaye, Site-Specific Art, 215. See also Kirsi Peltomaki, "Affect and Spectatorial Agency: Viewing Institutional Critique in the 1970s," Art Journal 66, no. $4(2007): 36 \mathrm{ff}$.

72 Kaye, Site-Specific Art, 11.

73 Kaye, Site-Specific Art, 191. Kaye refers to a statement made by Daniel Buren. 
professionals at several occasions, not least because the installation included a performance in which museum staff members were actively involved.

\subsection{Robert Morris's Amsterdam Project}

Robert Morris's Amsterdam Project: Specification for a Piece with Combustible Materials was first realized as a site-specific installation in 1969, at the Stedelijk Museum Amsterdam. [Figure 7] The installation was repeated at the same location in 2011.

Robert Morris used to work in the tradition of minimal art and conceptual art with a variety of art forms, including performance and installation art. ${ }^{74}$ In his writings, the artist familiarizes us with the idea that site-specific installations evoke a "present tense of space," because they are "temporary and situational, made for a time and place and later dismantled." 75 The first installation that made Robert Morris famous was Continuous Project Altered Daily (1969), executed at the Castelli Warehouse in New York. Over a period of several months, Morris took up residence in the warehouse and brought raw materials to the site, such as clay, water, cotton sheets, asbestos, felt, and wood. He used the place as a "construction site," continuously changing the spatial arrangement of the materials into new configurations, while people could watch him at work. ${ }^{6}$ Nothing remained of this project, except for photographic documentation and written reports.

In the same year, Morris participated in the aforementioned exhibition Op losse schroeven in the Stedelijk Museum, one of the first overviews of conceptual art and process art featuring a considerable number of site-specific installations. ${ }^{77}$ Morris's project consisted of a collection of inflammable materials, such as turf, branches, grass, and coal, that were arranged in a specific order on the gallery floor. Towards the end of the show, the artist handed over a set of instructions to the museum for the completion of the Amsterdam Project (see Appendix). He requested that

74 Initially a painter and sculptor, Morris co-operated with the Judson Dance Theater in the early 1960 , for which he choreographed a number of works.

75 In a series of essays, Robert Morris explains his views on site specificity: "Notes on Sculpture," published in Artforum (February and October 1966) and "The Present Tense of Space," Art in America (January-February 1978), reprinted in Continuous Project Altered Daily: The Writings of Robert Morris (Cambridge, MA: The MIT Press, 1994). This quote comes from the "The Present Tense of Space" in Continuous Project, 202.

76 Davidts and Paice, Fall of the Studio, 55.

77 See footnote 18 of this chapter. 


\section{Figure 7 The Amsterdam Project. Specifications for a Piece with Combustible Materials (1969) by Robert Morris. Collection Stedelijk Museum Amsterdam. Installation view in Op losse schroeven. Situaties en cryptostructuren. Photo: courtesy Stedelijk Museum Amsterdam. $\odot$ c/o Pictoright Amsterdam.}

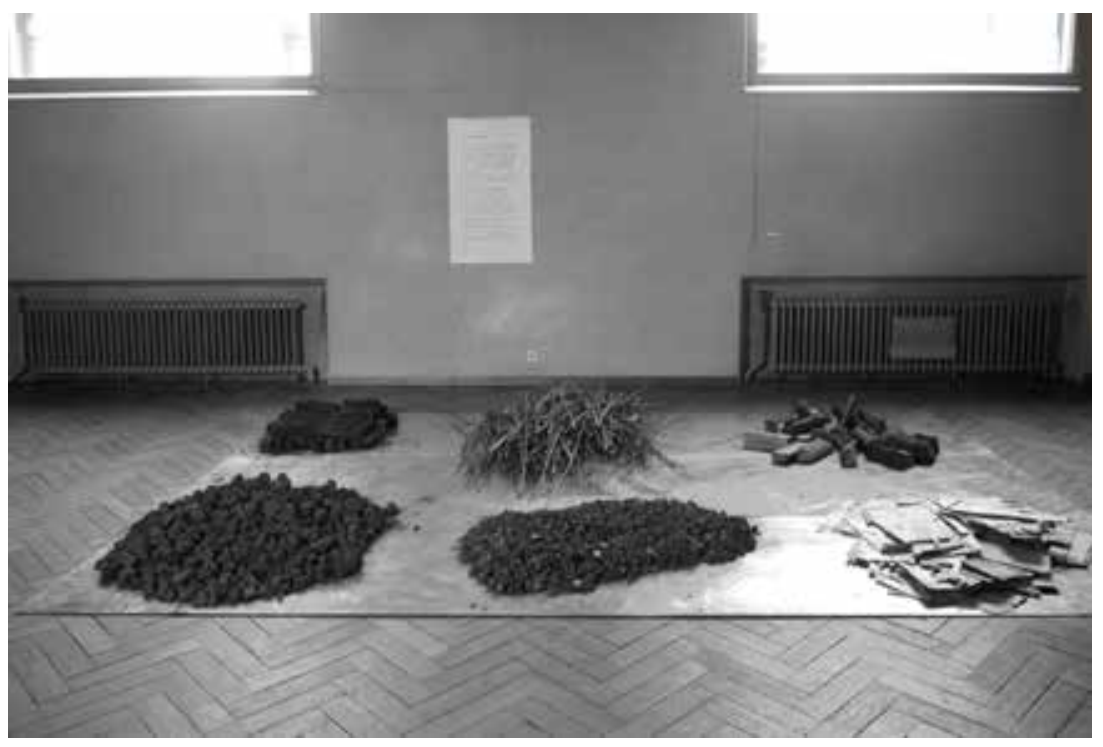

museum professionals carry out a performance by setting the combustibles on fire in front of the museum building. And so it happened in April 1969. The materials were brought to the front of the museum and were set on fire by the staff members, marking the end of this initial iteration of The Amsterdam Project. In accordance with the ideas of conceptual art, Morris allowed the Stedelijk Museum to restage the installation based on his instructions and to carry out the performance in a similar way. ${ }^{78}$

More than four decades later, in 2011, the Stedelijk Museum took up the challenge and re-executed The Amsterdam Project once more at the original location. At that time, the museum was right in the middle of a major

78 Conservator and scholar Sanneke Stigter explains that conceptual artworks in which the idea predominates the artwork's materialized form open up the vista that custodians can re-execute the artwork, although, in practice, questions of how "to cope with the dilemmas when having a responsibility towards the work's conservation and presentation" may still stand in the way of doing so without the presence of the artist. Sanneke Stigter, "Between Concept and Material. Working with Conceptual Art: A Conservator's Testimony” (PhD diss., University of Amsterdam, 2016), 36 . 
reconstruction, including renovation of the old building and the addition of a new wing. Before the Stedelijk would entirely be closed for a long time, it featured the series Recollections, restaging a number of artworks from $O p$ losse schroeven. ${ }^{79}$ Morris's Amsterdam Project was included and a similar set of materials was collected by the museum staff. ${ }^{80}$ The instructions were used to install the heaps of raw materials in the same room and with the exact same spatial arrangement as in 1969. In addition, as before, the show ended with a performance executed by the custodians, who set fire to the combustibles in front of the museum building. And, to convey the historical significance of the exhibition, visitors with a smartphone could take a virtual guided tour and experience $O p$ Losse Schroeven in the gallery spaces where the artworks had originally been displayed in 1969. In those cases where the original artworks could not be recreated, visual documentation and spoken word gave an impression of what the installation had been like at the time.

According to the museum's press release, Recollections restaged "one of the most innovative surveys" of the 1960 s, and Morris's project emphasized the role of the museum as a memory institution:

"Combustible" can be read as a criticism of the art world that places too much weight on technical virtuosity and the primacy of the object. Morris's critique is equally pertinent today and highlights a paradox of the current exhibition: in attempting to offer insights on a historical exhibition intended to subvert both the traditional art object and the traditional role of the museum, it must rely on objects from its own collection. ${ }^{81}$

The reinstallation of the Amsterdam Project puts dilemmas to the fore of re-executing a site-specific installation in the absence of the artist, even if it is intended this way in the concept of the work. With the original iteration, the artist made a powerful statement by bringing in combustible materials and letting them be burned by museum professionals, literally "troubling" the oppositions between the work and the site. Morris turned the museum regime upside down and yet intended his was work to being collected and re-executed. In the self-reflective statement cited above, the museum

79 Recollections - Op losse schroeven was curated by Margriet Schavemaker and Ann Goldstein, Stedelijk Museum Amsterdam, summer 2011.

80 Some of the artworks could not be refabricated and were presented in the form of documentation. A multimedia tour (including QR codes and GPS technology) explained the original location and meaning of the works.

81 See the press release, http://www.stedelijk.nl/en/press-releases/stedelijk-museum-presentsrecollections--op-losse-schroeven_(last accessed 22 April 2021). 
acknowledges that the reiteration of the installation and the performance in 2011 were not "subversive" acts in themselves, but ways to keep the memory of the original project alive. One could argue that this reactivation was in agreement with the artist's intention regarding the artwork's site specificity and his intent to interfere with museum practices. The exhibition space was still the same and the entire process was repeated, carefully following the artist's instructions in regard of the work's spatial arrangement and orchestration of the performance in front of the museum building.

That said, the impact of the restaged Amsterdam Project was completely different from its original iteration, not least because the sociocultural context had radically changed over forty years. Although the display setting was still anchored in the original location, the experience needed an explanation. To this end, much effort was put into communicating the historical context of Op losse schroeven to the public by means of a virtual tour, elucidating the initial site specificity of the works. After this final iteration, the building was renovated and with the disappearance of the original site it can be reasoned that a reconstruction like this can never be realized again.

\subsection{The Site of Production and the Site of Perception}

In the above literature review and introduction of case studies, the focus has been on artworks dating from the 196os and 1970s. In the following paragraphs, I will shift the discussion to the 1990s, when a renewed interest in site specificity emerged, both in the artists' production practices and the museums' collecting policies and exhibition programmes.

Influenced by the possibilities of travelling, globalization, and technological developments, artists of the 199os started to work across the globe, with well-known examples as Thomas Hirschhorn, Francis Alÿs, Mark Dion, and Renée Green. According to James Meyer, a large group of artists started to explore "a mobile notion of site and a nomadic subjectivity." ${ }^{82}$ Meyer describes this new form of site specificity in terms of the "functional site," moving it away from physically rootedness and institutional critique to a broader cultural sphere of investigation and communication. ${ }^{83}$

The functional work explores an "expanded" site: the "art world," in this activity has become a site within a network of sites, an institution among

82 Meyer, "Functional site," 32.

83 Meyer, "Functional site," 23-25. 
institutions. To be sure, previous institutional critique demonstrated the financial and ideological ties of the gallery to greater economic and political structures. [...] Today, much practice explores an expanded site, enlarging its scope of inquiry into contingent spheres of interest, contingent locations [and this practice] may engage several sites, institutions, and collaborations at once. ${ }^{84}$

The expanded notion of site specificity primarily applies to geographical site-specific projects. Quite often, site-specifıc working artists engaged with the history or geography of a particular place, and they often involved local communities in the production of their art. As Miwon Kwon also observes, in theory, any place, community, or social issue could prompt a site-specific work. The communication with "an audience," as was common in the 1990s, had largely replaced the fascination for site specificity of previous periods. ${ }^{85}$

Many geographical site-specific projects have resulted in a film, a series of photographs, or an archive, and these art objects (as they were considered) might easily find their way into a commercial gallery or museum. To some extent, the circulation of derivatives of land art projects of the 1960 s and 1970s are comparable, taking into account that Earthworks can still exist in the actual, physical environment, whereas these newer art productions were conceived as the main result of the project and circulated as "independent" artworks. The gap between the production site and the site of perception is denoted by Meyer as a "discursive" relationship and a juxtaposition of different "realities of site." ${ }^{86}$ Kwon therefore adds to her typology a third category - namely, that of discursive site-specific works:

This is not to say that the parameters of a particular place or institution no longer matter, because site-oriented art today still cannot be thought or executed without the contingencies of locational and institutional circumstances. But the primary site addressed by current manifestations of site-specificity is not necessarily bound to, or determined by, these contingencies in the long run. Consequently, although the site of action or intervention (physical) and the site of effects/reception (discursive) are conceived to be continuous, they are nonetheless pulled apart. ${ }^{87}$

84 Meyer, "Functional site," 27.

85 Kwon, One Place After Another, 109.

86 Meyer, "Functional site," 25-27; Kwon, One Place After Another, 26-30.

87 Kwon, "Notes on Site-Specificity," 45. Original emphasis. 
Also according to Meyer, the expanded notion of site does not necessarily imply that the spatiotemporal characteristics of the artwork are disregarded; they are just raised to another level, allowing for a potential coexistence of multiple site specificities, both real and virtual. Moving away from "the premise of site-specificity to locate the work in a single place, and only there," those strategies are primarily related to social and artistic practices. ${ }^{88}$ Hence, if we conceive site specificity this way, we could further explore its function as "an operation occurring between sites, a mapping of institutional and discursive filiations and the bodies that move between them (the artist's above all)." 89

It follows that, in conservation and presentation strategies applied during successive biographical stages of the artwork, all kind of mediation processes come into play. When fluid notions of a "discursive" and "mobile" site enter the art production as well as the discourse, the role of a "mediator" who presents these artworks to the public comes to the fore. Roles are shifting, and the person who takes on the function of mediator could either be the artist, the gallerist, or the museum curator - or a combination. In this respect, some critics emphasize that site specificity (and contemporary art in a broad sense) has primarily become a strategy of mediation; of connecting places and sites, art producers and art receivers. Martha Buskirk, for example, argues in The Contingent Object that contemporary art opens up "temporal gaps [...] at the level of production" and requires an act of mediation and interpretation:

This rift may appear in the very places where spatial and temporal experiences are the most important, as objects that depend on an unmarked uniformity are marked with the signs of age, as performances are known through partial documents or accounts, and as works initially installed or arranged with the artist's direct participation are increasingly interpreted by others. $9^{0}$

Following the idea that site specificity is not "fixed," but gradually unfolds as a network of relationships between the artwork and multiple sites, it sometimes happens that museums play an active role in the mediation of the work as "site-specific installation" (as we have seen with The Amsterdam

88 Meyer, "Functional Site," 26.

89 Meyer, "Functional Site," 25.

90 Martha Buskirk, The Contingent Object of Contemporary Art (Cambridge, MA: The MIT Press, 2003), 14 . 
Project), bridging the gap between the site of production and the site of perception. This "mobility" of site specificity is illustrated with the following case example of Phil Collins's geographical site-specific project and video installation they shoot horses (2004).

\subsection{Phil Collins's they shoot horses}

Phil Collins's installation they shoot horses, in the collection of Tate, consists of a two-channel video installation with sound, which is projected in a darkened space. [Figure 8] When Collins started the preceding geographical site-specific project in 2004, he lived and worked in Israel. Nine young volunteers from Ramallah were asked to perform a dance marathon of two days and record the dancing themselves..$^{91}$ They were provided with a nonprofessional camera and filmed each other mainly in close-up. Collins involved this local group of volunteers in creating the raw material for the installation in the same way that he used footage of reality TV for other art productions.

The meaning of they shoot horses is intertwined with the geography and sociopolitical situation in Ramallah, signifying not only the work's content but also the spatiotemporal conditions during the recording: the length of the performance and the location of the marathon were similar to dance events usually held in Ramallah; the screening of the artwork thus seems to represent the local situation. Claire Bishop describes this as follows:

It goes without saying that they shoot horses is a perverse representation of the "site" that the artist was invited to respond to: The occupied territories are never shown explicitly but are ever-present as a frame. [...] By using pop music as familiar to Palestinian as to Western teens, Collins also provides a commentary on globalization that is considerably more nuanced than most activist-oriented political art. ${ }^{92}$

91 The title refers to the novel They Shoot Horses, Don't They (1935) by Horace McCoy, in which dance marathons during the Great Depression of the 1930 are the central theme. For more information, see: http://www.tate.org.uk/art/artworks/collins-they-shoot-horses-t1203o (last accessed 22 April 2021).

92 Claire Bishop, "The Social Turn: Collaboration and its Discontents," Artforum International 44 (February 2006): 182. 
Figure 8 They shoot horses (2004) by Phil Collins. Collection Tate Galleries, London.
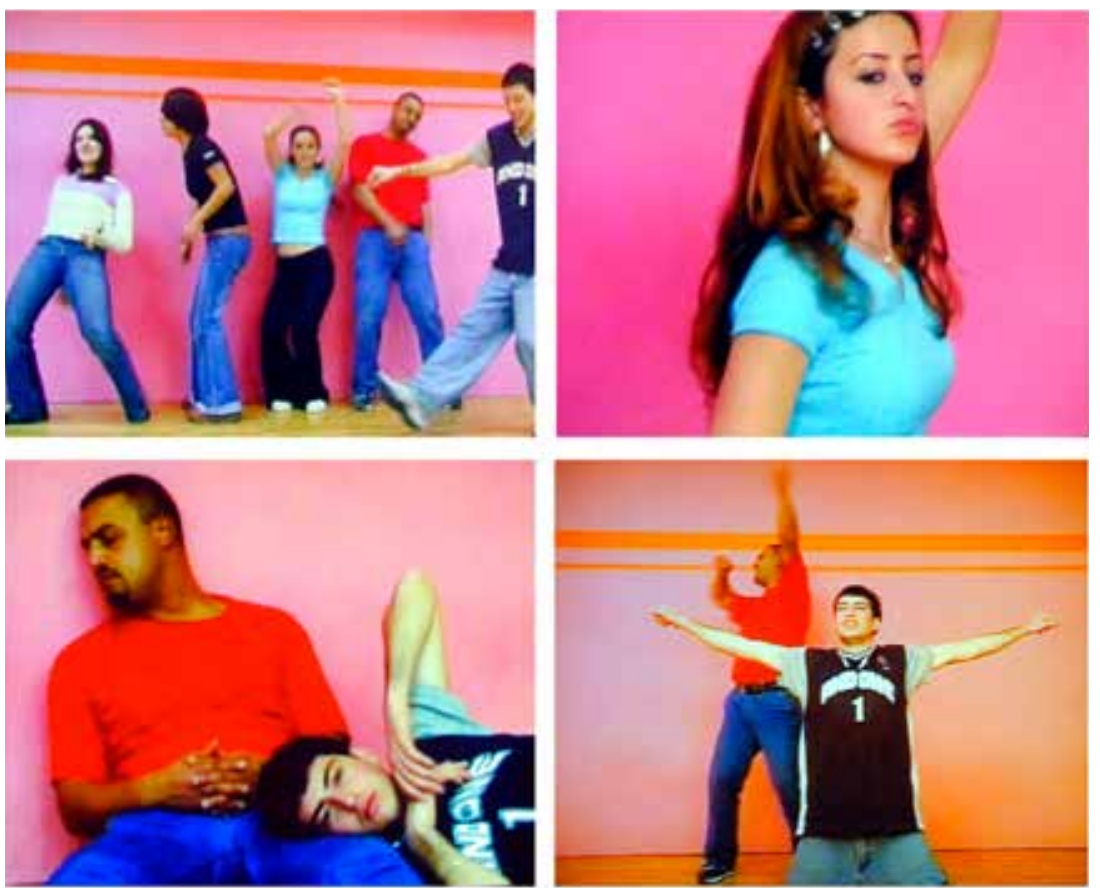

What the public may not have realized is that the artwork had to be accommodated to the museum conditions to be experienced at all. A second layer of site specificity was added to they shoot horses when the artwork was acquired and entered a stage of postproduction at the Tate: the raw footage was brought into the museum's technical department and, with the help of the artist and a team of conservators and curators, accommodated to a suitable work of art.

A case study carried out by Pip Laurenson during the Inside Installations project, demonstrates that Collins's preference for using a nonprofessional camera posed a challenge to the artwork's musealization, because the original footage was of insufficient quality for a museum screening. Moreover, the technicians expected a rapid degradation of the material. ${ }^{93}$ Hence, the

93 The case study was carried out by Pip Laurenson at the Tate during the European Inside Installations project (2004-2007) and has been published in Tatja Scholte and Paulien 't Hoen, ed., Project Preservation and Presentation of Installation Art (Amsterdam: Instituut Collectie Nederland, 2007), 9 . 
conservator and technicians of the Tate decided to transfer the footage to a more sustainable carrier and figure out an appropriate display. During this process, profound questions were posed in relation to the editing of the footage: what approach should be followed with regard to gaps in the footage resulting from technical failures during the dance marathon in Ramallah? How to treat the intervals when the calls for prayer from a nearby mosque interfered with the music? Should those calls be included or left out? And last but not least: one hour of footage had been lost when the material was confiscated at one of the Israeli checkpoints. How should this gap in the material be treated?

After discussions with the artist, it was decided to use a film-editing package and to cut the footage to a duration matching the opening hours of the Tate Modern, meaning six hours and forty minutes of dancing. The time slot was applied to both channels that were presented in the gallery in order to complete the installation. In other words, the real-time recording of they shoot horses was reconstructed to fit a site-specific installation, adjusting the work to the time-space co-ordinates of the gallery and presentation standards of the museum environment. Mediation, in this example, took place during the postproduction of the artwork with the support of advanced technology and was highly influenced by custodianship.

they shoot horses can be considered an illustration of what James Meyer and Miwon Kwon indicate as a discursive or mobile site, emerging in the movements and relationships between one site and the other. During the production and postproduction of they shoot horses, several stages of site specificity can be identified: firstly, the original sociogeographical location where the volunteers performed and filmed their own dancing in Ramallah; secondly, the travelling and the problems of smuggling the footage out of the country (and one part of it being confiscated); and thirdly, the postproduction in the technical department of the Tate, and the presentation of the artwork in the gallery. One question is not addressed in this context: what would happen if they shoot horses would be sent on loan. Would new adjustments regarding the duration of the screening have to be made to accommodate the work to another gallery space with different opening hours?

\subsection{Conclusion}

A number of notions support the analysis of the perpetuation of site-specific installations. The typology developed by Miwon Kwon set the terms for understanding site specificity as a multilayered phenomenon, which she 
takes apart in a genealogy of phenomenological, social-institutional, and discursive types of site specificity. The dividing line between the 1960s-1970s and the 1980s-1990s distinguishes the first two types from the third one, although Kwon acknowledges that these are overlapping categories in artistic practices. Based on James Meyer's discursive or mobile site, I elaborated on the functional mode of site specificity, situating the gallery or a museum as a "site" between other sites, for example, the site of the art project, the site of production, various sites of reception, the site of musealization, and so forth. The function of presenting a site-specific installation could thus be to bridge the gap between one and the other function of the "site." In respect to museum presentations, Nick Kaye pointed to the "performativity" of site-specific installations as an artistic strategy to activate the connection between the artwork and conditions of the site, posing challenges to the institutions when preserving and presenting the work of art. I put sitespecific installations in relation to Fernando Domínguez Rubio's suggestion of "unruly objects" that withdraw from the control mechanisms of the institutions and produce new forms, practices, and meanings, to varying degrees of continuity and change.

In chapter 1, I made the assumption that site-specific installation artworks are relational networks. Following Kevin Melchionne and Nick Kaye, I added the notion that site-specific installations can be understood as an artistic strategy and proposed to apply a set or network of site-specific functions to the analysis of their transformation over time. Still indebted to the Kwon's categorization, but bearing this notion in mind, I came up with the following set of site-specific functions, which can be activated when the installation is preserved and presented: first, the artwork's spatial design and its connection to the physical surrounding; second, the way in which a site-specific work activates the visitor's experience in the here and now and raises awareness of the sociocultural context; and third, the discursive dimension of site specificity, bridging the gap between the site of production and the site(s) of reception. The latter may reach beyond the installed artwork and take a variety of mediation forms, including photography, film, and other forms of documentation.

Various examples presented in this chapter show how diverse strategies are employed to reinvigorate site specificity in different contexts and times - by artists, conservators, curators, and art historians alike. Whereas the term site-specific suggests that these works are singular manifestations spatiotemporally defined like Serra's Tilted Arc - various authors took the position that these works can be reiterated, as the practices of museums and commercial galleries from the 1990 s onwards demonstrate. Mark Rosenthal, 
for example, takes the stance that reactivation of the work's site specificity can give the viewer a "real time and space" experience, despite the fact that the work is executed at different locations in different times (as, for example, Richard Serra's Splashing). And looking through the lens of the custodian, Tina Fiske proposes a strategy of "translation," ensuring that reinstallations of site-specific installation artworks are repetitions of a process of interaction between the work and the site, which may lead to radical solutions in the exhibition strategies.

Now that an overview has been provided of the history of site-specific installation art, and an inventory has been made of possible typologies and notions of site specificity, it is time to elaborate the conceptual model I propose for the analysis of site-specific installations artworks over time. In chapter 3, I will introduce Henri Lefebvre's The Production of Space to provide a descriptive set of site-specific functions. Furthermore, I will take a close look at contemporary art conservation to develop an analytical toolbox for tracing the factors of influence on successive iterations of site-specific installation artworks. 
